\title{
ANTIPOESIA, METAPOESIA E IRONIA NA OBRA POÉTICA DE NiCANOR PARRA $^{1}$
}

JoÃo Claudio ARENDT ${ }^{*}$

RAFAEL DE LUCENA IOTTI ${ }^{* * *}$

\section{RESUMO}

O objetivo deste artigo é analisar a questão da antipoesia e sua relação com a ironia e a metapoesia na obra do poeta chileno Nicanor Parra. Por ser um autor ainda pouco conhecido no Brasil, abordam-se, primeiro, alguns aspectos de sua vida e obra, por meio de levantamento de dados biobibliográficos. Em seguida, busca-se identificar os temas centrais na obra do poeta, para, finalmente, analisar, sob a perspectiva da antipoesia, da metapoesia e da ironia, uma seleta de poemas publicados em livros entre 1954 e 1963. Na base teórico-crítica utilizada, destacam-se, entre outros, Croce (1967), Fernández Retamar (1995), Schopf (2000), Cabañas (2003) e Muñoz (2009).

PalaVRas-ChaVe: Nicanor Parra. Antipoesia. Metapoesia. Ironia.

\section{INTRODUÇÃO}

Nicanor Parra é um dos maiores poetas em língua espanhola dos séculos XX e XXI. Porém, até pouco tempo, havia no Brasil apenas um

1 O presente artigo resulta do Trabalho de Conclusão de Curso em Letras, intitulado Chistes para desorientar a academia: a antipoesia na obra de Nicanor Parra (ARENDT, 2020), realizado com o apoio da Universidade Federal de Mato Grosso do Sul e da Coordenação de Aperfeiçoamento de Pessoal de Nível Superior - Brasil (CAPES) - Código de Financiamento 001 e Edital Universal.

** Docente permanente no Programa de Pós-Graduação em Letras da Universidade Federal do Espírito Santo (UFES).

E-mail: joaoarendt@gmail.com Orcid iD: https://orcid.org/0000-0002-2587-2521

*** Aluno de Mestrado do Programa de Pós-graduação em Letras da Universidade Federal do Rio Grande do Sul (UFRGS), Porto Alegre, Rio Grande do Sul, Brasil.

E-mail: iottirafael@gmail.com Orcid iD: https://orcid.org/0000-0002-2587-2521 
pequeno número de poemas seus em uma edição dividida com Vinícius de Moraes, publicada em 2009 pela Academia Brasileira de Letras, em parceria com a Real Academia Chilena de la Lengua. Essa lacuna foi parcialmente preenchida em 2018, com a publicação da antologia Só para maiores de cem anos, com tradução de Cide Piquet e Joana Barossi. A antologia traz aos brasileiros apenas uma pequena amostra da obra poética de Nicanor Parra, cuja obra completa soma mais de duas mil páginas e está esgotada.

Do ponto de vista da crítica, no Brasil, destacam-se a tese Antipoesia em Lear rey \& mendigo de Nicanor Parra, de Antonia Javiera Cabrera Muñoz - que se detém na tradução-criação e nos conceitos que Nicanor Parra transpõe de King Lear para o espanhol chileno - e o ensaio Nicanor Parra: a ruptura poética da antipoesia, de Ana Teresa Cabañas que aborda a questão da antipoesia comparando o autor com o cânone da poesia chilena (Vicente Huidobro, Pablo Neruda, Gabriela Mistral, Pablo de Rokha) e examinando aspectos relevantes do movimento iniciado por Parra.

Isso posto, no presente artigo busca-se contextualizar brevemente a trajetória pessoal do poeta chileno, identificar alguns temas centrais de sua obra e, em seguida, analisar uma seleta de poemas publicados em livros, entre os anos 1954 e 1963, sob a perspectiva da antipoesia, da metapoesia e da ironia.

\section{DAdos biobliográficos De NicANor PARRA ${ }^{1}$}

Nascido em 5 de setembro de 1914, em San Fabián de Alico, Chile, e falecido em 23 de janeiro de 2018, em La Reina, aos 103 anos, Nicanor Segundo Parra Sandoval era o mais velho de oito irmãos e cresceu em uma família de classe média provinciana cercada de artistas populares. $\mathrm{O}$ pai, Nicanor Parra, era professor e músico; a mãe, Rosa Clara Sandoval

As informações biobibliográficas de Parra foram colhidas em diferentes fontes, como sites de literatura, artigos acadêmicos e livros do autor. 
Navarrete, era costureira. Do círculo familiar, destaca-se a compositora, cantora e artista plástica Violeta Parra (1917-1967), irmã do poeta.

Em 1932, Parra mudou-se para Santiago de Chile, onde cursou o último ano do que hoje constitui o chamado Ensino Médio. No ano seguinte, ingressou no Instituto Pedagógico da Universidad de Chile, para estudar Matemática e Física. De maneira simultânea, também estudou engenharia, direito e inglês.

Em 1937, atuou como professor e ministrou aulas de física e matemática no Liceo de Hombres de Chillán. Nesse mesmo ano, publicou o primeiro livro, Cancionero sin nombre, com visíveis influências de García Lorca e com o qual obteve o Prêmio Municipal de Santiago, tendo o autor sido saudado pela poeta Gabriela Mistral como "futuro poeta do Chile".

No ano de 1943, possivelmente, aconteceu a grande reviravolta na vida do poeta. Com uma bolsa de estudos do Institute of International Education, Parra viajou para os Estados Unidos com o intuito de fazer uma pós-graduação em Mecânica Avançada na Universidade de Brown. Ficou em Rhode Island por três anos. Posteriormente, em 1946, voltou para o Chile como professor titular de Mecânica Racional no Instituto Pedagógico da Universidad de Chile. Nos anos seguintes, galgou posições na instituição, sendo nomeado Diretor Interino da Escola de Engenharia.

Em 1949, recebeu outra bolsa de estudos, agora para Oxford, na Inglaterra, onde estudou cosmologia. Nesse período, leu os autores que viriam a influenciá-lo por toda a vida, como Franz Kafka, Arthur Rimbaud e Walt Whitman. Descobriu escritores vanguardistas europeus, como os da chamada arte surrealista liderada pelos franceses André Breton, Paul Éluard e Louis Aragon, além dos poetas estadunidenses, que viveram na Inglaterra, como T. S. Eliot e Ezra Pound. Foi durante os anos que coincidem com sua estadia nos Estados Unidos e Inglaterra do pós-guerra, que a ideia de uma antipoesia começou a ser concebida.

No ano de seu regresso, em 1952, montou uma exposição chamada Quebrantahuesos, de colagens feitas com recortes de jornal, em parceria com os poetas Enrique Lihn e Alejandro Jodorowsky. Parra não deixaria de produzir essas collages até o fim de sua vida, retrabalhando-as e nomeando- 
as de "artefactos visuales", importante ferramenta para propagação da antipoesia, lembrada e estudada pelos críticos especializados em sua obra. Essas obras foram reunidas no livro Parra: artefactos visuales, pela Pinacoteca da Universidade de Concepción do Chile, em 2002.

Em 1954, 17 anos após publicar Cancionero sin nombre, veio a lume o seu livro mais célebre até hoje: Poemas y Antipoemas. A partir de então, dar-se-ia mais de meio século de fazer antipoético: La cueca larga (1958), Versos de salón (1962), Canciones rusas (1967), Obra gruesa (1969), Artefactos (1972), Sermones y prédicas del Cristo de Elqui (1977), Nuevos sermones y prédicas del Cristo de Elqui (1978), Chistes para desorientar a la policía (1983), Coplas de Navidad (1983), Hojas de Parra (1985), Poesía política (1983) e Poemas para combatir la calvicie (1993). O último livro publicado pelo poeta chileno é de 2006, Discursos de sobremesa.

\section{A ANTIPOESIA E SEUS SIGNIFICADOS}

Nicanor Parra não inventou o termo antipoesia. O poeta peruano Enrique Bustamente y Ballivián intitulou de Antipoemas o seu livro publicado em 1926. Vicente Huidobro, poeta chileno e um dos criadores do movimento estético chamado Creacionismo, inserido na vanguarda do Chile, incluiu a palavra antipoeta no seu livro Altazor, de 1931. E um pouco depois, em 1935, o termo aparece, no livro The descent of winter, do americano William Carlos Williams. Nesse mesmo período, em 1936, o filósofo e crítico italiano Benedetto Croce dedicava ao termo um pequeno capítulo intitulado "A poesia, a não poesia e a antipoesia", no seu livro $A$ poesia (1967).

Quando se trata de Parra, outras questões estão implicadas. Antipoesia, nesse sentido, seria uma expressão inovadora, uma escola, uma forma de encarar a vida e o mundo. Na medida em que ela se constitui um projeto estético, uma primeira pergunta é evidente: contra o que se diz anti e sobre qual pano de fundo está definida a sua oposição?

Na América Latina, a denominação antipoesia passou a ser sinônimo de Nicanor Parra. Entretanto, o termo também é empregado na Europa 
para nomear uma tendência poética mais generalizada e abrangente, sem os mesmos princípios de Parra. Ela é referida no livro $A$ verdade da poesia (2007), de Michael Hamburger, quando trata de poetas poloneses da segunda metade do século XX. Cabañas (2003, p. 197) afirma que a antipoesia está, nesse caso, associada a alguns poetas do pós-guerra e que ela "obedeceria à profunda desconfiança com a qual os poetas passam a se relacionar com os meios e procedimentos que até então vinham sendo utilizados pela lírica para manter sua autonomia. Uma condição existencial, aliás, em nada alheia à prática do poeta chileno"

O prefixo e elemento de composição "anti", de origem grega, exprime uma noção de oposição que coloca à coisa o contrário da coisa. Pode-se deduzir, portanto, que o termo, nesse caso, define, fundamentalmente, uma ruptura.

Para a crítica especializada na obra de Nicanor Parra, é quase um consenso que a antipoesia reagiu, à época, contra a norma dominante, contra aquilo que, no âmbito local e nacional, poderia ser definido como cânone ou vanguarda chilena. Os principais alvos, nesse sentido, seriam os poetas Pablo Neruda, Vicente Huidobro, Pablo de Rokha e, indiretamente, Gabriela Mistral. Sobre isso, Fernández Retamar (1995, p. 163) afirma:

[...] o nome [antipoemas] fez sucesso rapidamente, porque na época se falava da antinovela, antiteatro, antipintura... Porém, pelo mero fato de ser, nenhuma poesia é antipoesia: a única verdadeira antipoesia não se escreve. No entanto, a antipoesia, como no caso da antinovela, é anticerto tipo de poesia. Em se tratando de Parra, como vários autores vieram desde o primeiro momento, se trata de uma poesia antiNeruda.

Diante disso, há uma reformulação do sentido de poesia, conforme o uso feito por Nicanor Parra. Para os estudiosos já mencionados, a antipoesia estaria voltada ao cotidiano, às coisas não sublimes, à comunidade dos homens comuns. Assim, ao examinar o fenômeno, podese constatar que ele é uma oposição à poesia dita "pura".

Há, portanto, uma ruptura estética. Os antipoemas estão perfilados contra o lírico, em que se utiliza a linguagem coloquial e uma visão em 
certo sentido pessimista, irônica e anárquica que pretende desmanchar o mundo, para, então, refazê-lo.

Por mais que Fernández Retamar (1995) afirme que a antipoesia de Parra seja, antes de tudo, "antiNeruda”, faz-se necessário considerar que Pablo Neruda publicou, em 1935, quase 20 anos antes de Poemas y antipoemas, um ensaio que iria ao encontro do que Parra proporia mais tarde. Nesse manifesto, Neruda (1995, p. 457) afirma: "Assim seja a poesia que buscamos, gasta, como por um ácido, pelos deveres da mão, penetrada pelo suor e pelo fumo, cheirando a urina e açucena, salpicada pelas diversas profissões que se exercem dentro e fora da lei."

Neruda redige esse manuscrito influenciado pelo movimento artístico chamado Realismo Social e/ou Realismo Socialista, em voga como política de Estado para a estética na então União Soviética, que perdurou até a década de 1960. Para Neruda, essa seria a única estética politicamente possível.

Entretanto, de acordo com Cabañas (2003, p. 199),

Embora o poeta [Neruda] fixe residência na terra e suas sejam as de impureza, ele continua sendo a voz sublime, aquele que restabelece, portanto, o diálogo entre a terra, matéria que apodrece, e o que a transcende, o próprio poético [...] De modo que, coincidindo outra vez com Hamburger, vemos, então, que raramente as declarações sinceras dos poetas conseguem materialização efetiva.

Assim, a personalidade poética de Neruda encontra dificuldades para contemplar o que ele mesmo propõe nos seus manifestos. No ensaio que dedica à antipoesia, Ibañez Langlois (1976, p. 21) pontua:

O sujeito nerudiano é o protagonista superlativo e excepcional de experiências privilegiadas [...] ego criador que, tão terrestre e angustiado quanto se queira, é sempre uma deidade situada no meio de seu mundo-espetáculo, que recolhe os tormentos de um cosmos que só diante dele parece dissolver-se, como em outros tempos só para o poeta cantavam os bosques e o vento. 
Determinado a fazer poemas não convencionais, diferentemente de seus conterrâneos e contemporâneos, e do que se poderia chamar de status quo da poesia chilena - e até de si mesmo, se se toma o primeiro livro Cancionero sin nombre -, Nicanor Parra propõe a inclusão do cotidiano e do prosaico de forma positiva no poema, como se não pertencessem de fato à literatura. Essa manifestação é vista, pela primeira vez, em Poemas y antipoemas (1954).

Parra não aborda, assim, somente temas eternos da poesia, como tempo, morte, amor, memória etc., mas, também, os transitórios, de modo que o autor propõe uma apresentação transitória do permanente. Para Muñoz (2009, p. 14), trata-se de uma nova inclusão de temáticas com coloquialidade, "tratando de comunicar-se com o leitor comum. Em sua arte poética, o poeta fala com seus pares, que são muitas personagens: o provinciano que chega à cidade, o adúltero, o bêbado, o predicador exaltado, o morto e o ressuscitado, o órfão e o mendigo [...]"

Por mais que, em um primeiro momento, a antipoesia tenha se inserido no panorama literário como uma oposição à forma estabelecida pelos poetas canônicos em língua espanhola, é uma limitação encarar o fenômeno antipoético apenas por esse viés, como se estivesse à sombra ou invariavelmente fundido ao poeta Pablo Neruda. Em Parra, a antipoesia torna-se uma atitude vital de índole própria, e nisso reside a impossibilidade de determinar conceitualmente a sua essência.

Mesmo assim, é factível afirmar que a posição assumida por Parra é frontalmente oposta à visão de poesia que Croce (1967, p. 14) apresenta:

A ação da poesia pareceu tão admirável e quase milagrosa aos antigos gregos que eles a consideraram como um sopro sagrado, um furor, um entusiasmo, uma divina mania, e distinguiram os aedos dos demais mortais, honrando-os como inspirados pelos deuses, discípulos diletos da Musa cujo canto alcança o amplo céu. Nem mesmo os modernos negam este preito de homenagem e, de fato, costumam cercar os poetas de unânime admiração e quase reverente proteção.

Croce (1967, p. 73) ainda compara a antipoesia à coisa feia, de desvalor: "a antipoesia e o feio são outra coisa, e consistem na interferência 
da vontade, que projeta os seus objetivos práticos para dentro do processo da formação artística, assim como a mesma interferência no processo do pensamento é o erro ou o falso."

Em outra perspectiva, a noção de antipoesia assemelha-se a uma definição formulada por $\operatorname{Paz}(2013$, p. 65), quando escreve sobre os escritores e poetas românticos europeus do século XIX:

Para todos os fundadores - Wordsworth, Coleridge, Hölderlin, Jean Paul, Novalis, Hugo, Nerval -, a poesia é a palavra do tempo sem datas. Palavra do princípio: palavra de fundação. Mas também palavra de desintegração: ruptura da analogia pela ironia, pela consciência da história que é consciência da morte (PAZ, 2013, p. 63).

Já Friedrich (1978, p. 16-17) afirma que

A poesia moderna não quer mais ser medida em base ao que comumente se chama realidade, mesmo se - como ponto de partida para a sua liberdade - absorveu-a com alguns resíduos. [...] Das três maneiras possíveis de comportamento da composição lírica - sentir, observar, transformar - é esta última que domina na poesia moderna e, em verdade, tanto no que diz respeito ao mundo como a língua.

Na obra de Nicanor Parra, também se vê essa vontade de transformação. No entanto, ela não é maior do que os outros comportamentos possíveis da composição poética.

Se se pudesse determinar uma posição primeira, entre as três ranqueadas por Friedrich, em Parra estaria justamente a de "observar". Para os poetas modernos, tanto românticos como vanguardistas, procurava-se evitar a intimidade comunicativa. Em Parra, ao contrário, há a necessidade de comunicação, transmissão da experiência vivida, porque, se ele fala sobre os típicos personagens que Muñoz (2009) apresenta, essa mensagem precisa também chegar até eles.

Possivelmente, a ruptura seja a maior subversão da estética de Parra. Parece bastante claro que o poeta chileno atua contra uma poesia pura, inserindo, na sua própria criação, outros elementos prosaicos. Gombrowicz 
(1989) afirma que não gostam da poesia pura pelas mesmíssimas razões que os levam a não gostar de açúcar puro. Essa afirmação poderia, muito bem, ter sido feita pelo poeta chileno aqui em estudo.

Entretanto, a visão de Nicanor Parra sobre a antipoesia, em uma entrevista com o escritor uruguaio Mario Benedetti, é outra. Para Parra (1969, p. 13-15), a antipoesia - ou o seu projeto literário - deve "criar vida em palavras: realmente isso é o que me pareceu que teria de ser a poesia”.

\section{Antipoesia, metapoesia e ironia na obra de Nicanor ParRa}

Postas essas considerações iniciais, é preciso deixar claro que o que se propõe aqui não é uma análise das obras completas de Nicanor Parra, porque a soma de seus livros ultrapassa duas mil páginas. Para tanto, um recorte é necessário, e o olhar voltar-se-á para alguns poemas dos livros Poemas y antipoemas (1954), Versos de salón (1962), La Camisa de Fuerza (1962) e Manifiesto (1963), compreendendo menos de 10 anos de produção antipoética.

Nesse recorte, Nicanor Parra contrapõe-se ao vanguardismo cristalizado e à poesia dita profunda, especificamente dos poetas chilenos de diferentes gerações. É possível encontrar aí um eu lírico que colhe a palavra do uso cotidiano, que se pretende fazer retornar à realidade de maneira potencializada e acessível ao público. Parra, nessa perspectiva, faz uso, de forma direta e impactante, de uma poética que de fato diz, evitando cifrar e ocultar.

A linguagem coloquial que Parra utiliza a partir de Poemas $y$ antipoemas estabelece laços de aproximação com o leitor. O impacto resultante dessa prática acaba gerando diversas leituras a seu respeito. Para o crítico Schopf (2000, p. 268, tradução nossa),

O reconhecimento das formas e, sobretudo, o tom coloquial do falante produzem a ilusão de familiaridade com o discurso, mesmo que esta familiaridade entre em conflito com os modelos de poesia que integram o seu horizonte de expectativas e que provem do modernismo e 
das vanguardas. Não suspeita que sob esta familiaridade se arraste um efeito de estranheza que rapidamente envolve os materiais entregues na recepção. ${ }^{2}$

Essa linha de pensamento corrobora a afirmação de que o poeta utiliza discursos conhecidos e, a partir deles, elabora uma nova estética no âmbito da poesia. Ou, como já se afirmou anteriormente, propõe uma apresentação transitória do permanente. Algumas dessas marcas são reconhecíveis em sua antipoesia, como aponta Cabañas (2003, p. 200):

[...] imersão no inconsciente coletivo, ampliação do espaço lúdico através do humor, fragmentação do discurso e a técnica de montagem, utilização de um material discursivo pertencente a um registro não estético - como frases ou slogans publicitários, sentenças e ditos populares [...] Contudo, dentre esses traços há um que resulta mais decisivo para o entendimento da sua proposta: a carregada dessublimação da figura do poeta e da poesia.

Nesse sentido, o tema principal da antipoesia talvez seja a própria antipoesia. Ao encarar de frente a imponência do legado da poesia numa totalidade - englobando aí os parnasianos, os modernistas e os vanguardistas, principalmente os poetas que influenciaram a estética de Parra, bem como a grandiloquência profética da poesia de Pablo Neruda com seu engajamento político -, "era necessário que Parra abrisse um espaço meio que às cotoveladas" (BINNS, 2018, n. p.).

Para essa abertura de espaço, foram precisos diversos manifestos, declarações de princípio e ataques ao cânone estabelecido, aos leitores e aos críticos que os consagravam. Por vezes, essas expressões eram pacíficas, indiretas, sutis, mas, em outras, agressivas e violentas.

2 El reconocimiento de las formas y, sobre todo, el tono coloquial del hablante le producen la ilusión de familiaridad con el discurso, apesar de que esta familiaridad entra en conflicto con los modelos de poesía que integran su horizonte de expectativas y que provienen del modernismo y las vanguardias. No sospecha que bajo la familiaridad se desliza un efecto de extrañeza que envuelve rápidamente los materiales entregados en la recepción. 
Também a vertente metapoética acompanhou Nicanor Parra no decorrer de sua carreira. A metapoesia, em definição rápida, é poesia que descreve e questiona o próprio fazer poético. Portanto, para se teorizar a respeito da poesia de Parra, deve-se considerar a estruturação metapoética das suas antipoesias. No próprio interior dos poemas, tem-se esse caráter híbrido de teoria, crítica, manifesto e poesia, e é por meio dessa autorreferenciação que se chega à base dos antipoemas.

Em outros poetas, percebe-se a intenção de criar metapoemas para explicar uma determinada visão sobre a poesia, enquanto em Nicanor Parra a metapoesia é a poesia. E é nessa diferença sutil que a antipoesia de Parra mostra-se original na literatura hispano-americana da segunda metade do século XX, já que desde primeiros trabalhos o poeta constrói metapoeticamente a sua concepção da antipoesia.

Binns (2018, n.p., tradução nossa), a metapoesia "é prova tanto de uma autorreflexividade quase narcisista como de uma constante busca

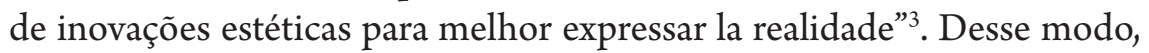
no primeiro poema da terceira seção do livro Poemas y antipoemas, Parra arremete-se contra o seu leitor:

\section{Advertência ao leitor}

O autor não responde pelos incômodos que seus escritos possam [provocar:

Ainda que lhe doa

O leitor terá que se dar sempre por satisfeito.

Sabellius, que além de teólogo foi um humorista consumado, Depois de ter reduzido a pó o dogma da Santíssima Trindade Acaso respondeu por sua heresia?

E se chegou a responder, como o fez!

De que forma descabelada!

Segundo os doutores da lei este livro não deveria ser publicado:

A palavra arco-íris não aparece em nenhuma parte,

3 "es prueba tanto de una autorreflexividad casi narcisista como de una búsqueda constante de innovaciones estéticas para mejor expresar la realidade”. 
Ainda menos a palavra dor,

A palavra torcuato.

Já cadeiras e mesas aparecem a granel,

Ataúdes! apetrechos de escritório!

$\mathrm{O}$ que me enche de orgulho

Porque, a meu ver, o céu está caindo aos pedaços.

Os mortais que tenham lido o Tractatus de Wittgenstein

Podem se dar por satisfeitos

Porque é uma obra difícil de conseguir:

Porém o Círculo de Viena se dissolveu faz anos,

Seus membros se dispersaram sem deixar rastros

E eu decidi declarar guerra aos cavalieri di la luna.

Minha poesia pode perfeitamente não conduzir a lugar nenhum

"As risadas deste livro são falsas", argumentarão meus detratores

"Suas lágrimas, artificiais!"

"Em vez de suspirar, nestas páginas se boceja"

"Se esperneia como uma criança de colo"

"O autor se faz entender aos espirros"

De acordo: convido-os a queimar suas naves,

Como os fenícios pretendo formar meu próprio alfabeto.

“Para que incomodar o público, então?”, se perguntarão os amigos

[leitores:

"Se o próprio autor começa desprestigiando seus escritos,

O que se pode esperar deles?"

Cuidado, eu não desprestigio nada

$\mathrm{Ou}$, melhor dizendo, eu exalto meu ponto de vista,

Me vanglorio de minhas limitações,

Coloco nas nuvens minhas criações.

Os pássaros de Aristófanes

Enterravam em suas próprias cabeças

Os cadáveres de seus pais.

(Cada pássaro era um verdadeiro cemitério voador)

A meu ver 
Está na hora de modernizar esta cerimônia

E eu enterro minhas plumas na cabeça dos senhores leitores! (PARRA, 2018, p. 31-32)

Esse longo poema tem uma importância simbólica na obra de Nicanor Parra, porque é o estopim, talvez a maior manifestação até o momento, de sua estilística inovadora. A metapoesia está representada desde o primeiro, até o último verso. $O$ poeta começa se autodefendendo das críticas que seu livro poderá receber, dos impactos que poderá causar. Como se fosse suscetível, coloca-se em uma posição de alguém que pode ser atacado e, por isso, ataca antes.

Tem-se, então, um diálogo quase teatral entre o antipoeta e o seu público, ou seja, os seus detratores. O tom de agressividade do poeta, que por vezes pode parecer gratuita, é uma marca constante na obra de Parra. Como se mencionou anteriormente, a violência inserida na estética do antipoeta é direcionada para, ao menos nesse primeiro momento, a poesia vigente no seu país de origem.

A principal novidade instaurada aqui, que marca uma ruptura e um novo modelo de fazer poesia, é que, com a criação de uma nova fórmula com a qual o escritor "se vangloria de suas limitações", a linguagem e a temática realizam uma aproximação bastante sincera com a realidade. Além disso, o antipoeta não tem a pretensão de ser um profeta iluminado, muito diferente daquela ideia de poesia que se encontra em Benedeto Croce. Pelo contrário, o antipoeta celebra a sua visão parcial das coisas, a pequenez do seu limitado ponto de vista: "eu exalto o meu ponto de vista, / me vanglorio de minhas limitações” (PARRA, 2018, p. 32).

Sobre essa pretensa nova fórmula, Rodríguez Fernández (2007, p. 17, tradução nossa) afirma:

Essa incorporação de termos tradicionalmente alheios à poesia revela, do ângulo da linguagem a mesma tentativa de dessacralização que vimos no que diz respeito ao locutor lírico e à função poética; no entanto, é preciso dizer que esta tarefa foi iniciada por Pablo Neruda em alguns poemas da Residencia en la tierra, por exemplo: "Walking 
around" e "Caballero solo" e, com muito mais vigor, na poesia anglófona para via W.H. Auden, T.S. Elliot e outros. ${ }^{4}$

O crítico aponta, então, caminhos já antes trilhados por outros poetas - sobretudo grandes poetas que Parra havia lido no período em que morou na Inglaterra. No entanto, a forma de dessacralização utilizada pelo poeta chileno difere, principalmente, do tom adotado pelos poetas de língua inglesa, que, segundo Rodríguez Fernández (2007), utilizam-na com mais vigor.

De acordo com Ayala (2010), a coloquialidade parriana pressupõe uma falsa inocência advinda da poesia e da cultura popular. Nela, há um tom mais relaxado e, em princípio, não interessado na musicalidade, por mais que ele use constantemente o hendecassílabo espanhol:

A diferença na obra de Nicanor Parra está na quantidade e na performance expressiva que consegue dar à dicção poética: tanto na linguagem coloquial quanto no uso de sua sintaxe desgastada no e tom relaxado, o que igualmente nega a musicalidade modernista (apesar do uso constante do hendecassílabo), a falsa inocência da poesia popular, a fragmentação fria da vanguarda e o tom elevado da poesia política e a intimidade individualista da poesia lírica. ${ }^{5}$ (AYALA, 2010, p. 38, tradução nossa)

No livro Versos de Salón, além de trocar as referências mais usuais de uma poesia pura (arco-íris por cadeiras, por exemplo), Nicanor Parra dá

4 Esta incorporación de términos tradicionalmente ajenos a la poesía, revela desde el ángulo del lenguaje la misma tentativa de desacralización que hemos visto a propósito del hablante lírico y de la función poética; sin embargo, es necesario decir que esta tarea había sido iniciada por Pablo Neruda en algunos poemas de Residencia en la tierra, por ejemplo: "Walking around" y "Caballero solo" y, con mucho mayor vigor, en la poesía de habla inglesa a través de W. H. Auden, T. S. Elliot y otros

5 La diferencia de la obra de Nicanor Parra se encuentra en la cantidad y el rendimiento expresivo que logra dar a la dicción poética: tanto en el lenguaje coloquial como en el uso de su sintaxis deshilachada y el tono relajado, que reniega por igual de la musicalidad modernista (a pesar de su constante uso del endecasílabo), de la falsa inocencia de la poesía popular, de la fragmentación fría de la vanguardia y del tono elevado de la poesía política y del intimismo individualista de la lírica. 
um passo adiante nessa modificação de referências imaginárias, quando, no poema "Mudanças de Nome", afirma que "o poeta não cumpre sua palavra / Se não muda os nomes das coisas” (PARRA, 2018, p. 51). Veja-se:

\author{
Por que motivo o sol \\ Continuará se chamando sol? \\ Peço que se chame Micifuz \\ Aquele das botas de quarenta léguas! \\ Meus sapatos parecem ataúdes? \\ Saibam vocês que de hoje em diante \\ Os sapatos se chamam ataúdes. \\ [...] \\ Até o nome de deus é preciso mudar \\ Que cada um o chame como quiser: \\ Esse é um problema pessoal.
}

(PARRA, 2018, p. 51)

Fica claro que mudar o nome das coisas implica criar uma nova identidade para elas, uma nova acepção, outorgando um novo significado aos objetos. E isso somente é possível por meio da ressignificação total. Agora, o poeta não se satisfaz mais em inserir novas palavras ou palavras de fora da poesia tradicional no seu projeto estético, como, por exemplo, os "ataúdes". A sua ambição é de outro gênero: passa do nível lexical para o semântico. No final do poema, o sujeito lírico desprende-se da responsabilidade com um chiste irônico, não reinventando o nome de deus, já que isso diz respeito a um problema pessoal. Dirige-se, mais uma vez, ao leitor, para que ele mesmo realize essa mudança de nome.

As alterações de nome são bastante representativas na estética de Parra e possibilitam vislumbrar melhor em que lugar está inserida a metapoesia no projeto do escritor: além de uma troca de conceitos, nomes, ideias e objetos, há a problematização da manutenção da poesia. Existe, portanto, uma crítica ao status quo ocupado de antemão pelos poetas.

Percebe-se, ainda, uma linguagem bastante coloquial e prática, ou seja, o poeta busca clareza no modo de se expressar, mesmo deixando algumas lacunas ao receptor. As respostas nunca dão conta de todas as 
perguntas, o que vem ao encontro do primeiro poema analisado, quando o antipoeta diz: "minha poesia pode perfeitamente não conduzir a lugar nenhum” (PARRA, 2018, p. 32).

Assim como a metapoesia, outras características estão presentes no cerne da estilística parriana: fazem parte dos seus principais recursos poéticos o humor e a ironia. Morales (1998, p. 11, tradução nossa) assevera que:

O antipoema, em primeiro lugar, é subversivo mas não militante: não assume um lado ideológico, é, antes, um acusador vigilante das deformações das ideologias. $\mathrm{O}$ sistema antipoético inclui entre seus elementos: um personagem anti-heróico que observa dentro das casas ou enquanto se move por lugares públicos em espaços urbanos; humor, ironia ou sarcasmo, que trazem à luz o oculto, que tornam o óbvio suspeito, que cavam e tornam visível um vazio sob o que parecia sólido ou confiável, e um verso cujo vocabulário, entonação e sintaxe não obedecem mais a um modelo literário, mas à linguagem prosaica que se fala todos os dias e em cada esquina. $\mathrm{O}$ antipoema dilacera $\mathrm{o}$ leitor e o mundo cotidiano que ele habita, mas ele não o faz sem se expor, porque ele mesmo está envolvido, como estrutura, no jogo de significados: seu próprio corpo linguístico está igualmente dilacerado. ${ }^{6}$

A entonação que aproxima a ironia do humor pode ser encontrada nos poemas analisados. Mudanças de nome, por exemplo, também são um golpe desferido nos poetas grandiloquentes da época. A partir do

6 El antipoema, en primer lugar, es subversivo pero no militante: no toma partido ideológico, sino es más bien un vigilante acusador de las deformaciones de las ideologías. El sistema antipoético incluye entre sus elementos: un personaje antiheroico que observa en el interior de las casas o mientras se desplaza por los lugares públicos de los espacios urbanos; el humor, la ironía o el sarcasmo, que sacan a luz lo oculto, que vuelven sospechoso lo evidente, que cavan y hacen visible un vacío debajo de lo que parecia sólido o confiable, y un verso cuyo léxico, entonación y sintaxis ya no obedecen a un modelo literario, sino al prosaico lenguaje hablado de todos los días y en todos los rincones. El antipoema desgarra, al lector y al mundo cotidiano que este habita, pero no lo hace sin exponerse, porque él mismo está implicado, como estructura, en el juego de las significaciones: su propio cuerpo lingüístico se presenta igualmente desgarrado. 
momento em que se muda o significado das coisas, também se muda a forma como se encaram essas coisas: mudando o nome dos objetos, mudase, por consequência, o modo como a poesia é feita. Além de ser um absurdo - que não se enquadra em regras e condições preestabelecidas -, é também um exagero. Nessa perspectiva, Propp (1992, p. 88) é categórico ao afirmar que "a comicidade tem sempre a ver com o exagero".

Parra ainda caracteriza, em muito de seus poemas, a figura do antipoeta, sempre na perspectiva do humor, da comicidade e da ironia. Por isso, pode-se perguntar: o que é o antipoeta senão uma caricatura do antipoeta? Em "Autorretrato", lê-se:

Considerem, garotos

Esta língua roída pelo câncer:

Sou professor em uma escola obscura

Perdi a voz dando aulas.

(Depois de tudo ou nada

Faço quarenta horas semanais.)

O que acham desta cara esbofeteada?

Verdade, inspira lástima de me olhar!

E o que dizer deste nariz comido

Pela cal deste giz mais degradante?

Em matéria de olhos, a três metros

Não reconheço nem minha própria mãe.

O que me afeta? - Nada.

Eles se arruinaram durante as aulas.

A dura luz, o sol,

A venenosa lua miserável.

E tudo, para quê

Para ganhar um pão imperdoável

Duro que nem a cara do burguês.

E com sabor e com cheiro de sangue.

Para que nascemos como homens

Se nos dão uma morte animalesca!

Graças ao excesso de trabalho, às vezes

Vejo formas estranhas pelos ares, 
Ouço corridas loucas,

Risos, conversas criminais.

Observem estas mãos

E estas bochechas brancas de cadáver,

Estes escassos cabelos que me restam,

Estas negras rugas infernais!

E no entanto eu fui como vocês,

Jovem, cheio de belos ideais,

Sonhei fundir o cobre

E limar as faces do diamante:

Aqui estou agora

Por trás desta banca insuportável

Embrutecido pela batucada

Das quinhentas horas semanais.

(PARRA, 2017, p. 29)

E em “Epitáfio", do mesmo livro:

De estatura mediana,

Com uma voz nem fina nem grossa,

Filho mais velho de um professor primário

E de uma costureira doméstica;

Magro de nascimento

Ainda que adorador da boa mesa;

De faces esquálidas

Mas, sim, abundantes orelhas;

Com um rosto quadrado

Em que os olhos muito mal se enxergam

E um nariz de boxeador mulato

Sobre uma boca de ídolo asteca

- Tudo isso banhado

Por uma luz entre irônica e pérfida -

Nem muito esperto nem doido varrido

Fui o que fui: uma mescla

De vinagre e azeite de oliva

Um embutido de anjo e de besta!

(PARRA, 2018, p. 30) 
Em ambos os poemas, é apresentado o rebaixamento desse eu lírico (ou seja, do antipoeta) ao nível do patético e do ridículo, com uma caricatura que ora faz rir, ora inspira compaixão.

No primeiro, tem-se a situação de um professor cujo conhecimento repetitivo e mecânico produz um embrutecimento atroz, ao invés de libertá-lo. Como a antipoesia poderia cantar à moda dos outros poetas, se o antipoeta, tal qual em "Autorretrato", perde a voz e somente mediante isso ganha o pão? Por isso, a antipoesia não canta, mas conta. E, por mais que ele cante, não há a perda da plurissignificação que caracteriza a poesia em seu melhor estado. Como pontua Wittgenstein (2017, p. 43), um dos filósofos preferidos de Parra, "não se esqueça que um poema, mesmo que composto na linguagem da informação, não é usado no jogo de linguagem de dar informação.”

Em "Autorretrato", portanto, é criado um vínculo com a realidade trivial e não com a estética. Composto em versos livres, não há referências mitológicas ou literárias. No centro do poema, está a atividade de professor, um dos ofícios do poeta chileno. Quando se trata da linguagem, nos poemas vistos até agora, não há extravagâncias, pois tudo é talhado na simplicidade brutal e proletária: "cara esbofeteada; nariz comido".

Percebe-se, ainda, uma voz que relata a impotência angustiante de viver em um mundo desigual. Os abusos contra o trabalhador conduzemno a proferir, no fim do poema, a ironia que provoca no leitor um sorriso amargo. O professor, no início do poema, afirma trabalhar 40 horas semanais e, no último verso, elas tornam-se 500. O desencanto, por fim, parece ser a maior lição que esse professor dá aos seus alunos, como se a única conclusão possível fosse justamente a impossibilidade de alcançar o êxito das metas sociais e pessoais.

De acordo com Binns (2018, n.p), "mais frequente e mais complexo, em Parra, é o uso de uma ironia dramática, no sentido de que nem o autor nem nós acreditamos ou levamos a sério tudo o que diz o sujeito do poema."

Essa ironia nem sempre se resolve com uma resposta, posto que o poeta rechaça os significados literais das coisas, mas não os substitui por 
outros. Não é oferecida ao leitor alguma solução ou qualquer apoio. Binns (2018, n.p., tradução nossa) diz que esse fenômeno

É a ironia do desamparo, típico de um mundo sem sentido. Ou seria, se não fosse pelas risadas. Porque também vimos poemas em que o antipoeta ri dos personagens carrancudos que se deixam dominar por um mundo incrédulo e alienante. Há críticos que distinguiram o riso alegre dos poemas populares de Parra do riso mais amargo e ambivalente dos antipoemas. Há, é claro, uma diferença: o riso antipoético é parte de uma crítica implacável da sociedade e de si mesmo.Dói e chora, mas também responde à euforia às vezes sentida pelo autor, pelo leitor e pelos personagens antipoéticos, sentindo-se livre (por mais precária e efêmera que seja a liberdade) das camisas de força ideológicas com que o mundo o contemporâneo nos controla ${ }^{7}$.

No poema "Epitáfio", o menosprezo por si mesmo obedece à descrição de qualidades médias do antipoeta. O título é sarcástico, porque foi publicado já no seu primeiro livro, e um epitáfio corresponde a, basicamente, uma inscrição que se põe na lápide de uma pessoa ao final da vida.

O poema em questão busca invocar a vida pessoal do eu lírico e o faz muito bem até certo ponto: quem foram seus pais, sua vida econômica, sua posição social. Entretanto, as características psicológicas, "um embutido de anjo e de besta", manifestam com clareza a autossabotagem do eu lírico. Na geração de poetas passados, esse "eu poético" costumava aparecer revestido de solenidades e prestígios. E Parra não vê o poeta como sujeito especial e transcendental.

Es la ironía del desamparo, propia de un mundo que carece de sentido. O lo sería, si no fuera por la risa. Porque también hemos visto poemas en que el antipoeta se ríe de los personajes con el ceño fruncido que se dejan vencer por un mundo descreído y enajenante. Hay críticos que han distinguido la risa alegre de los poemas populares de Parra de la risa más amarga y ambivalente de los antipoemas. Existe, desde luego, una diferencia: la risa antipoética es parte de una crítica despiadada tanto de la sociedad como del sí mismo. Duele y desgarra, pero también responde a la euforia que sienten, en ocasiones, el autor, el lector y los personajes antipoéticos, al sentirse libres (por muy precaria y efímera que sea esa libertad) de las camisas de fuerza ideológicas con que el mundo contemporáneo nos controla. 
O epitáfio, assim, funciona como uma despedida do mundo (talvez do mundo poético) com suas últimas palavras. O poeta escolhe desvirtuar a seriedade da poesia vigente e prefere rir de si mesmo. Os seus traços, desde então, não apontam para uma vida extraordinária, mas, sim, medíocre e comum. Sobre essa espécie de anti-herói parriano, Rodriguez Fernández (2007, p. 19, tradução nossa) afirma que

É alguém que está absolutamente longe da transcendência metafísica, é um sujeito 'nem muito inteligente, nem muito estúpido', um ser concreto de origens muito claras: 'filho de professora primária e de costureira'; Em outras palavras, não é mais uma entidade historicamente indefinida cuja única determinação é sua capacidade de sofrer e ansiar pelo absoluto (como é o caso do locutor lírico de Residencia en la tierra), mas sim um sujeito histórico capaz de ironizar sua situação vital. ${ }^{8}$

A ironia só é possível a partir dos movimentos realizados pelo seu criador, como propõe Duarte (1994, p. 55):

De fato, nada pode ser considerado irônico se não for proposto e visto como tal; não há ironia sem ironista, sendo este aquele que percebe dualidades ou múltiplas possibilidades de sentido e as explora em enunciados irônicos, cujo propósito somente se completa no efeito correspondente, isto é, numa recepção que perceba a duplicidade de sentido e a inversão ou a diferença existente entre a mensagem enviada e a pretendida.

Outro poema que ilustra bem a mescla das duas características aqui examinadas (metapoesia e humor/ironia) da antipoesia de Parra é “Test”:

8 Se trata de alguien absolutamente lejano a la trascendencia metafísica, es un sujeto 'ni muy listo, ni muy tonto', un ser concreto con orígenes muy claros: 'hijo de un profesor primario y de una modista de trastienda'; es decir, ya no se trata de un ente indefinido históricamente cuya única determinación es su capacidad de sufrimiento y de anhelo de lo absoluto (como es el caso del hablante lírico de Residencia en la tierra), sino de un sujeto histórico capaz de ironizar su situación vital. 
Test

Qué es un antipoeta:

Un comerciante en urnas y atáudes?

Un sacerdote que no cree en nada?

Un general que duda de sí mismo?

Un vagabundo que se ríe de todo

Hasta de la vejez y de la muerte?

Un interlocutor de mal carácter?

Un bailarín al borde del abismo?

Un narciso que ama a todo el mundo?

Un bromista sangriento

Deliberadamente miserable?

Un poeta que duerme en una silla?

Un alquimista de los tiempos modernos?

Un revolucionario de bolsillo?

Un pequeño burgués?

Un charlatán?

un dios?

un inocente?

Un aldeano de Santiago de Chile?

Subraye la frase que considere correcta.

Qué es la antipoesía:

Un temporal en una taza de té?

Una mancha de nieve en una roca?

Un azafate lleno de excrementos humanos

Como lo cree el padre Salvatierra?

Un espejo que dice la verdad?

Un bofetón al rostro

Del Presidente de la Sociedad de Escritores?

(Dios lo tenga en su santo reino)

Una advertencia a los poetas jóvenes?

Un ataúd a chorro?

Un ataúd a fuerza centrífuga?

Un ataúd a gas de parafina?

Una capilla ardiente sin difunto? 


\section{Marque con una cruz}

La definición que considere correcta.

(PARRA, 2017, 128)

O poema trabalha com a impossibilidade de definição tanto da antipoesia quanto do antipoeta. Dessa maneira, está estruturado em duas partes: a primeira dá conta de encaixar o poeta em alguma das categorias. Os seus desdobramentos levam, por consequência, a outras questões, até o fechamento irônico e surpreendente dos últimos versos. $O$ poeta propõe, então, ao leitor uma espécie de desafio, testando-o. Ao buscar resolver a provocação, o leitor não encontrará a definição adequada a respeito das indagações, porque ela não existe.

Deve-se entender que a natureza do poeta chileno e da estética que inaugura é por si só contraditória. Sobre isso, Goellner (2011, n.p., tradução nossa) comenta que:

Ao longo do poema, e não raramente na mesma frase, encontramos recursos de contradições, paradoxos e oposições. Além desses recursos presentes em "Teste", as respostas oferecidas como opções terminam em pontos de interrogação. Os pontos de interrogação colocados onde teríamos as respostas possíveis, que deveriam ser como afirmações e não como perguntas, causam certo desconforto e soam dissonantes. Estamos diante de um recurso que remove a possibilidade de uma resposta direta e abre a possibilidade de outras questões ${ }^{9}$.

Chega-se à conclusão de que é impossível, de maneira objetiva, obter alguma resposta, ou seja, o poema não admite que o leitor defina o que são o antipoeta e a antipoesia. No entanto, pode-se afirmar que o

9 En todo el poema, y no raramente dentro de una misma oración, encontramos recursos de contradicciones, paradojas y oposiciones. Además de estos recursos presentes en "Test", las respuestas ofrecidas como opciones terminan con puntos de interrogación. Los puntos de interrogación puestos donde tendríamos las posibles respuestas, que deberían estar como afirmaciones y no como preguntas causa un cierto incomodidad y suena disonante. Estamos delante de un recurso que aleja la posibilidad de una respuesta directa y nos abre posibilidad a otras preguntas. 
poeta está muito mais interessado em promover a discussão desses termos, do que simplesmente em defini-los. Conforme Goellner (2011, n.p.), entende-se que a discussão "sobre o conceito de antipoesia pode não ser o mais importante para a compreensão da obra de Parra, mas pode servir de estímulo para despertar nossas curiosidades e preocupações sobre a antipoesia e o antipoeta."

O funcionamento literário de “Test”, proposto por Parra, está bem alinhado ao seu projeto de antipoesia. E parece irônico o poeta - que, como se viu, foi matemático, físico, cientista - trabalhar justamente no campo da abstração surrealista, indefinida, absurda. O senso de humor e o sarcasmo agem como recursos subversivos não apenas neste poema, mas em todos os examinados até o momento. Nicanor Parra não projeta a sua inteligência com o intuito de estabelecer uma distância entre a realidade e o mundo privilegiado da criação excepcional. Ao contrário, ridiculariza a realidade e a mostra como um absurdo que pensa, por um momento, ser lógico. $\mathrm{E}$ ridiculariza, como consequência, a própria poesia, apresentando-a como um discurso "sublime" dessa realidade - escancarado, por exemplo, no verso “Un alquimista de los tiempos modernos?", que é uma referência ao poeta Pablo Neruda.

\section{Considerações Finais}

Na poesia de Parra, não existe a pretensão de o eu lírico propor a revelação de uma realidade superior, nem a busca de uma verdade existencial absoluta. Sua intenção básica é mostrar uma realidade imediata, desmascarando o elitismo rebuscado que esconde o rosto verdadeiro e triste do homem comum e da sociedade por meio de artifícios e extravagâncias poéticas. $\mathrm{O}$ autor prefere ir direto ao ponto, sem grandes subterfúgios de linguagem, de modo que, inclusive, o leitor comum possa fruir os seus poemas. Mas é claro que esse leitor não pode prescindir de algum conhecimento sobre a composição poética, já que tanto a ironia quanto a metapoesia exigem certo preparo e domínio da leitura. 
No que diz respeito à antipoesia, ficou claro neste artigo que Nicanor Parra não criou o termo. Ele surgiu nas primeiras décadas do século XX, mas foi o poeta chileno que lhe deu dicção e sentido especiais. Na sua obra, ela constitui um projeto estético de expressão inovadora e com uma forma inédita de encarar a vida e a própria poesia. Para tal, o autor lança mão de estratégias de composição, como a metapoesia e a ironia. No caso da primeira, é a reflexão sobre o fazer poético que se destaca, mas não no sentido convencional da crise criativa do sujeito lírico: é antes uma provocação sobre o papel da poesia - e do poeta - na sociedade. A ironia, por sua vez, dá o tom crítico à metapoesia presente no projeto estético da antipoesia parriana.

ANTIPOETRY, METAPOETRY AND IRONY IN THE POETIC WORK OF NiCANOR PARRA

\section{Abstract}

This article aims to analyze the antipoetry and its relation to irony and metapoetry in the work of the Chilean poet Nicanor Parra. As an author still little known in Brazil, first, some aspects of his life and work are approached, through the collection of bio-bibliographic data. Then, the aim is to identify the central themes in the poet's work, to finally analyze, from the perspective of antipoetry, metapoetry and irony, a selection of poems published in books between 1954 and 1963. On the theoretical and criticism, we highlight, among others, Croce (1967), Fernández Retamar (1995), Schopf (2000), Cabañas (2003) and Muñoz (2009).

KEYwORDS: Nicanor Parra. Antipoetry. Metapoetry. Irony.

Antipoesía, metapoesía e ironía en la obra poÉtica de NicANor Parra

\section{RESUMEN}

Este artículo pretende analizar el tema de la antipoesía y su relación con la ironía y la metapoesía en la obra del poeta chileno Nicanor Parra. Por ser un autor aún 
poco conocido en Brasil, primero se abordan algunos aspectos de su vida y de su trabajo a través de la recopilación de datos biobibliográficos. Luego, se busca identificar los temas centrales en la obra del poeta para, finalmente, analizar - desde la perspectiva de la antipoesía, de la metapoesía y de la ironía - una selección de poemas publicados en libros entre 1954 y 1963. Entre las referencias teórico-críticas utilizadas se destacan Croce (1967), Fernández Retamar (1995), Schopf (2000), Cabañas (2003) y Muñoz (2009).

Palabras ClaVE: Nicanor Parra. Antipoesía. Metapoesía. Ironía.

\section{REFERÊNCIAS}

AYALA, Matias. Lugar incómodo: poesía y sociedad en Parra, Lihn y Martínez. Santiago: Ediciones Universidad Alberto Hurtado, 2010.

BINNS, Niall. Aproximaciones de la obra de Nicanor Parra. Revista Universidad De Pensamiento y Cultura De La BUAP, n. 33, p. 4-37, 2018.

CABAÑAS, Ana Teresa. Nicanor Parra: a ruptura poética da antipoesia. Expressão, v. 1, n. 1, p.196-202, 2003.

CROCE, Benedeto. A poesia. Tradução Flavio Loureiro Chaves. Porto Alegre: A Nação, 1967.

DUARTE, Lélia Parreira Duarte. Ironia, humor e fingimento literário. Cadernos de Pesquisa, n.15, p. 61-63, 1994.

FERNÁNDEZ RETAMAR, Roberto. Para una teoría de la literatura hispanoamericana: primera edición completa. Santafé de Bogotá: Imprenta Patriótica del Instituto Caro y Cuervo, 1995.

FRIEDRICH, Hugo. Estrutura da lírica moderna: metade do século XIX a metade do século XX. Tradução Dora F. da Silva. São Paulo: Duas Cidades, 1978.

GOELLNER, Letícia M. V. S. ¿Es posible definir la antipoesía? ¿Quién sería el antipoeta? Un análisis del poema Test, de Nicanor Parra, buscando respuestas a estas preguntas. Mafuá, v. 17, n. 17, 2011.

GOMBROWICZ, Witold; PERÉT, Benjamin. Contra os poetas. Lisboa: Antígona, 1989. 
HAMBURGER, Michael. A verdade da poesia: tensões na poesia moderna desde Baudelaire. São Paulo: Cosac Naify, 2007.

IBAÑES LANGLOIS, José Miguel. La poesia de Nicanor Parra: Nicanor Parra; Antipoemas. Barcelona: Seix Barral, 1976.

IOTTI, Rafael. Chistes para desorientar a academia. Orientadora: Carina M.M. Niederauer. 51 f. TCC (Graduação) - Curso de Letras - Licenciatura, Universidade de Caxias do Sul, Caxias do Sul, 2020. Disponível em: https:// repositorio.ucs.br/11338/6361. Acesso em: 13 jan. 2021.

MORALES, Leonidas. Diccionario Enciclopédico de las Letras de América Latina. Caracas: Monte Ávila Editores, 1998.

MUÑOZ, Antonia Javiera. Antipoesia em Lear rey \& mendigo de Nicanor Parra. 2009. 251 f. Tese (Doutorado) - Universidade Federal de Santa Catarina, Florianópolis, 2009.

NERUDA, Pablo. Sobre uma poesia sem pureza. In: SCHWARTZ, Jorge. Vanguardas latino-americanas: polêmicas, manifestos e textos críticos. São Paulo: Edusp, 1995.

PARRA, Nicanor. El último apaga la luz: obra selecta. 2. ed. Santiago de Chile: Penguim Random House Grupo Editorial, 2017.

PARRA, Nicanor. Obras completas \& algo + (1935-1972). Barcelona: Ediciones Galáxia Gutemberg, 2006.

PARRA, Nicanor. Só para maiores de cem anos. Tradução Joana Barossi Cide Piquet. São Paulo: Editora 34, 2018.

PARRA, Nicanor; MORAES, Vinícius. Nicanor Parra y Vinicius de Moraes. Rio de Janeiro; ABL; Santiago de Chile: Academia Chilena de la Lengua, 2009.

PARRA, Nicanor. Nicanor Parra: o el artefacto com laureles. Entrevista concedida a Mario Benedetti. Revista Marcha, p. 13-15, 17 oct. 1969.

PAZ, Octávio. Os filhos do barro. Tradução Ari Roitman e Paulina Wacht. 2. ed. São Paulo: Cosac Naify, 2013.

PROPP, Vladimir. Riso e comicidade. São Paulo: Ática, 1992.

RODRIGUEZ FERNÁNDEZ, Mario. Nicanor Parra, destructor de mitos. Archivo Chile: Centro de Estudios Miguel Enriquez (CEME), 2007. 
SCHOPF, Federico. A medio siglo del Antipoema. Santiago: El Mercurio, 2000. WITTGENSTEIN, Ludwig. Fichas (Zettel). Lisboa: Edições 70, 2017.

Submetido em 07 de agosto de 2020

Aceito em 10 de dezembro de 2020

Publicado em 14 de fevereiro de 2021 